Print ISSN: 2288-4637 / Online ISSN 2288-4645

doi:10.13106/jafeb.2020.vol7.no6.073

\title{
Determinants of Sustainability Disclosure: Empirical Evidence from Vietnam*
}

\author{
Anh Huu NGUYEN ${ }^{1}$, Linh Ha NGUYEN ${ }^{2}$
}

Received: March 30, 2020 Revised: April 04, 2020 Accepted: May 01, 2020

\begin{abstract}
The paper investigates the effect of the factors on the disclosure of sustainable development information of enterprises. The research sample includes 120 manufacturing companies listed on Vietnam stock market in 2019. This research uses ordinary least squares (OLS) to address econometric issues and to improve the accuracy of the regression coefficients. The empirical results show that five variables have a statistically significant positive effect on disclosure of sustainable development information of manufacturing companies, including firm size (SIZE), independence of board of directors (BOD), foreign ownership (FRO), return on equity (ROE), and financial leverage (LEV). The results indicate that state ownership (STO) has a statistically significant negative effect on disclosure of sustainable development information of manufacturing companies listed on Vietnam stock market. Besides, the research results also show there is a large difference in the disclosure of sustainable development information between listed companies in Vietnam, those of other emerging economies in the region, and the companies in developed markets. Therefore, this paper provides a new insight to managers and related parties on how to improve the firm's sustainability disclosure to bring benefit for the firm itself and the stakeholders by reasonable decisions about the factors that affect disclosure of sustainable development information.
\end{abstract}

Keywords : Vietnam Stock Market, Sustainability Disclosure, Sustainable Development Information, Vietnam

JEL Classification Code: G32, G40, M41, M14

\section{Introduction}

The research of determinants of sustainability disclosure of enterprises is an important topic in the field of sustainable development. Up to date, most research on this issue is conducted in the developed markets and has shown mixed results about the effect of the factors on sustainability disclosure. This paper is informed by the context of emerging markets where very few empirical studies have been

*This research was funded by the National Economics University (NEU), Hanoi, Vietnam. The authors thank anonymous referees for their contributions and the NEU for funding this research.

${ }^{1}$ First Author and Corresponding Author. Dean, School of Accounting and Auditing, National Economics University, Vietnam [Postal Address: 207 Giai Phong Road, Dong Tam Ward, Hai Ba Trung District, Hanoi, 113068, Vietnam] Email: anhnh@neu.edu.vn

${ }^{2}$ Lecturer, School of Accounting and Auditing, National Economics University, Vietnam. Email: halinh1510@gmail.com

(c) Copyright: The Author(s)

This is an Open Access article distributed under the terms of the Creative Commons Attribution Non-Commercial License (http://Creativecommons.org/licenses/by-nc/4.0/) which permits unrestricted noncommercial use, distribution, and reproduction in any medium, provided the original work is properly cited. conducted. Especially, Vietnam is an important transition economy, and this is one of the first papers on this topic in the context of Vietnam where institutional environment, market information environment, and the market regulations are different from other countries. This paper investigates the determinants of sustainability disclosure in Vietnam. This research employs a data set of 120 manufacturing companies listed on the Vietnam stock market in 2019. The paper utilizes the Ordinary Least Square (OLS) of econometric techniques for the data set.

Although manufacturing is the most important sector in the economy, there is still no studies conducted in Vietnam to evaluate the sustainability disclosure as well as identify the factors that affect the disclosure of sustainable development information of manufacturing companies listed on Vietnam's stock market. Therefore, this research really makes sense in theory and practice. The research results should help the government to set up tighter and more appropriate regulations and policies to promote the stable development of the stock market, create fairness among listed enterprises, and protect the interests of investors. On the other hand, this research also helps enterprises in the manufacturing sector to 
see clearly the role, responsibility as well as the benefits of sustainability disclosure of their businesses.

Sustainability disclosure can be divided into two forms: mandatory and optional. The mandatory sustainability disclosure relates to the operation of the business. It is often stipulated by the government agencies and businesses must comply. The optional sustainability disclosure is highly voluntary, showing the spirit of integration as well as the sustainable development strategy of the business. Through transparent and accountable sustainability information, businesses strengthen the confidence of stakeholders in their businesses and the economy in general. Information disclosure promotes many aspects of enterprises' business activities.

Sustainability disclosure requires enterprises to pay attention to the interests of related parties, who may be affected by the operation of the enterprises, and to the business activities. Stakeholders can be employees, customers, suppliers, organizations, communities, investors, government and the media. Disclosure of sustainable development information significantly increases the value of a business's reputation and business performance through building trust with various stakeholders (Arifur, Mohammad \& Javed, 2013).

This paper consists of six sections. Following the introduction, Section 2 describes the theoretical framework. Sections 3 reviews the literature and develops hypotheses. Section 4 describes the data collection, variables, and regression model. Section 5 presents empirical results and discussion. Finally, Section 6 provides some policy implications and concluding remarks.

\section{Theoretical Framework}

\subsection{Stakeholders Theory}

Stakeholder theory refers to the management of the relationship between related parties and the company's responsibilities with those parties. Because effective management of the relationship between stakeholders is important to the company's image and competitive advantage, how much resources are allocated for managing the relationship, including the voluntary sustainability disclosure in annual reports, is important. Stakeholder theory suggested that potential stakeholders include shareholders, creditors, suppliers, managers, customers, competitors, employees, employees' families, the media, local communities, local charities, and future generations all influence the organization's voluntary sustainability disclosure. Currently, many businesses are being closely monitored for their actions, not only by shareholders and investors, but also by many other stakeholders such as customers, creditors, suppliers, community, and environmental activists. This reflects the increasing demand from many stakeholders groups and the importance of social and environmental issues related to globalization.

\subsection{Proprietary Cost Theory}

Many international studies have found empirical evidence that the cost of proprietary is one of the most important factors when a company discloses sustainability information. Fadun (2014) suggested that the proprietary cost was considered as an important limitation of information disclosure, a competitive disadvantage affecting the decision to provide private information. When voluntarily disclosure information on sustainable development, it is possible that the company will incur costs due to declining future cash flow from the disclosure of this information, but it is likely to increase later in different ways. Therefore, large-scale companies are more likely to voluntarily disclose sustainability information.

\subsection{Agency Theory}

Agency theory shows the relationship between the managers and the owners. They have a common goal of benefits but they are not always the same. The agency theory states that, if both parties in this relationship (the owners and the managers) want to maximize their interests, then there is reason to believe that the manager of the company will not act in the best interest of the owners that are the shareholders. Agency theory explains why annual reports are providing voluntarily information to creditors and shareholders. The separation of ownership and control of a company leads to conflicts of interest between the parties. Owners can limit conflicts by establishing appropriate incentives for managers and thereby generating supervision costs to limit the unusual activities of the managers.

\subsection{Political Economy Theory}

The theory of political influence states that managers such as the state, trade unions or community groups make decisions related to the interests of the company (such as tax policies, monopoly restrictions, and competition) based on the information disclosed by companies. To avoid the inspection and control by the authorities, companies will disclose more sustainable development information to limit the costs incurred when being inspected. On the other hand, when the information is voluntarily disclosed, managers expect state management policies to be loosened.

\subsection{Signaling Theory}

Signal theory posits that a company's financial decisions are signals sent by managers to investors to consider 
feedback. This signal is the basis for the company's financial communication policy. Signal theory assumes that wellperforming companies often use financial information as a signaling tool to market. In case the company wants to raise capital, more information disclosure will help the company attract the attention of investors, making it easier to raise capital. As such, the manager can disclose corporate sustainability information to users of financial statements, so that users can assess the performance of the business appropriately.

\subsection{Rationality Theory}

The theory of rationality states that companies cannot exist unless their value is considered socially appropriate. Accordingly, companies must take actions that society desires to ensure its continued existence. This theory argues that rationality is a generalization or assumption that the actions of an entity are desirable and appropriate in some social systems built from values and beliefs. The theory of rationality plays an important role in explaining the behavior of enterprises in the voluntary disclosure of information related to economic, social and environmental issues. The social assessment of an organization's performance is reflected in the information it discloses in accordance with society's expectations.

\section{Literature Review and Hypothesis Development}

\subsection{Literature Review}

Habbash (2016) investigated the impact of corporate governance on the level of corporate social responsibility disclosure of Saudi businesses. This study surveyed 267 annual reports of companies listed on Saudi Arabia's stock market from 2007 to 2011, using multivariate regression analysis and using a list of 17 indicators disclosure of social responsibility information based on ISO 26000. The results show that the level of disclosure of social responsibility information of these enterprises is $24 \%$, and the research results also show the state ownership, ownership of the managers, firm size and age of the company are factors that positively influence the level of information disclosure. The debt ratio is a negative factor, while the independence of the board of directors, the CEO's duality, profitability, and business lines are the factors that do not show any effect on the level of disclosure of social responsibility information of these enterprises. In addition, Huynh (2020) showed that good corporate governance will reduce earnings management by unethical behavior of managers and to enhance social responsibility actions by companies. The research by Lee (2018), levearaging a sample consiting of 749 firm-year observations of Korean listed companies in the period 2013 -2016 , showed that group-affiliated firm are less engaged in corporate social responsibility activities.

Arifur, Mohammad and Javed (2013) studied the relationship between corporate governance and the level of disclosure of sustainability information through the annual reports of companies in Bangladesh. The authors selected 135 manufacturing companies listed on the Dhaka Stock Exchange of Bangladesh from 2005 to 2009. The results of the study found a positive relationship between the ownership of managers, foreign ownership, the independence of the board of directors and the presence of audits to the extent of disclosure of sustainable development information by businesses.

Tagesson, Blank, Broberg and Collin (2009) examined the level and content of disclosing sustainable development information of 169 companies listed on the Stockholm Stock Exchange and all state-owned corporations in 2007. The results show the relationship between firm size and profit and the content of sustainable development information disclosure.

Hussainey, Elsayed and Razik (2011) studied the factors affecting the disclosure of sustainable development information in Egypt by collecting and analyzing data of 111 companies listed on the Egyptian stock market over the period 2005 to 2010. The research examines the influence of individuals on the disclosure of sustainable development information, including firm size, profitability, liquidity, capital structure, ownership type and audit firm. The research results found that the profitability of the company is an important factor that positively affects the disclosure of sustainable development information. Financial statements audited by an audit firm other than the "Big Four" also affect the disclosure of information in the direction of less information disclosure, but this effect is relatively weak. Besides, the authors did not see any relationship between firm size, liquidity, capital structure, ownership type and the disclosure of sustainable development information.

Baimukhamedova, Baimukhamedova and Luchaninova (2017) investigated the relationship between disclosures of corporate financial information in the annual reports with firms' costs of equity capital. The research sample consists of 37 largest and most liquid firms listed on Kazakhstan Stock Exchange (KASE) and the results showed that the higher the level of financial information disclosure, the lower the costs of equity capital of firms. The research results also indicated that, by enhancing the level of voluntary corporate disclosures, the listed firms on KASE might reduce their cost of equity capital.

Muttanachai (2015) studied 100 companies listed on Thailand Stock Exchange over 2013-2014. The results found the factors affecting the disclosure level of sustainable development information are firm size, type of industry, and company origin. Auditing and awarding corporate social 
responsibility companies are factors that do not affect the disclosure of sustainable development information.

There are few research papers on disclosure of sustainable development information in the context of Vietnam. Le (2015) studied the factors affecting the level of disclosure of social responsibility information in Vietnam through analyzing the annual report of 78 large-scale enterprises listed on the Ho Chi Minh stock exchange in 2014. The empirical research results show that the level of social and environmental disclosure is positively and significantly correlated with the size, profitability and age of the company, while leverage and characteristics of the industry does not show a relationship with the level of disclosure of social responsibility information. Ho and Liafisu (2014) surveyed 20 enterprises listed on Vietnam stock market over three years from 2012 to 2014 and stated that financial performance and debt leverage are the factors that affect the disclosure of information in economic, environment and society in the annual reports of Vietnamese enterprises.

\subsection{Hypothesis Development}

\subsubsection{Firm Size and Disclosure of Sustainable Development Information}

Most previous studies indicate that firm size has an impact on the level of voluntary disclosure of sustainable development information. Research by Ho and Taylor (2007) has found that larger companies disclosed more financial and non-financial information than small companies. The reason is because large-scale companies often have many and diverse investors, so the demand for information disclosure is higher. Empirical research conducted by Habbash (2016); Sadia, Tariq and Saba (2015) found a positive correlation between firm size and the level of disclose sustainable development information of enterprises. Political cost theory explains that large-scale companies are often the subject of much attention from regulators, so they often voluntarily disclose more sustainable development information to create transparency in information, avoiding inspection and examination by state agencies. In fact, for large companies with a large number of shareholders, shareholders often have concerns about environmental and social activities as well as the disclosure of information about these activities (John \& Senbet, 1998). Based on these studies, it is possible to expect a positive relationship between firm size and the disclosure of sustainability information. Therefore, the proposed hypothesis is as follows:

H1: The larger the enterprise, the higher the sustainable development information disclosure.

\subsubsection{Independence of Board of Directors and Disclosure of Sustainable Development Information}

According to agency theory, the board of directors with a high level of independence will be more effective in monitoring and controlling the activities of the company. Therefore, it is expected to be more successful in raising the value of the company's activities in sustainably and creating high transparency. When independent board members are involved in developing the company's business strategies and policies, they are believed to be able to evaluate management performance more objectively than the other the board members. Besides, independent board members are less dependent on the will of the chairman of the board than the remaining members. Therefore, a high proportion of independent board members of the company is expected to carry out better supervision and control of management activities (Le, 2015).

Indeed, research has shown that independent members of board of directors have much support in investing in the company's sustainable development activities and paying more attention to the public's social impact awareness compared to other members of the board of directors (Mohamed, 2012). Moreover, previous studies show that the board of directors with a high proportion of independent members tends to facilitate transparency and disclosure of sustainable development information (Gray, Kouhy \& Lever, 1995). This shows that the independent members of the board of directors can support the disclosure of social responsibility activities for sustainable development to reduce information asymmetry between insiders and outsiders of the company. Therefore, the proposed hypothesis is as follows:

$\mathrm{H} 2$ : Enterprises with higher level of independence of members of the board of directors will have higher level of disclosure of sustainable development information

\subsubsection{Ownership of Managers and Disclosure of Sustainable Development Information}

The effect of the ownership factors of managers on the disclosure of sustainable development information has been of interest to accounting researchers for a long time. Most studies show that the ownership of managers is negatively related to the level of voluntary disclosure of sustainable development information (Harry \& Linda, 1994). When ownership is concentrated in managers, it will allow them to dominate the company, determine the company's social behavior strategies and policies, including the disclosure of sustainable development information (Harry \& Linda, 1994). According to Ahmad (2014), the dominance of family members in corporate governance leads to the development 
of a tendency to make important decisions in family meetings before making decisions at official company meetings. For these companies, social responsibility may not be an important issue, because the interests of people outside the company are relatively small. Therefore, it is understandable that they are limited in disclosure of information about sustainable development.

Also, because the public interest in companies with high ownership percentage by managers is often relatively low, these companies may be less active in environmental activities and society. In other words, the managers of these companies may not invest heavily in socially responsible activities because the cost of investing in these activities may outweigh its potential benefits. Therefore, companies with low levels of sustainability information disclosure are often expected to be companies with high ownership percentage of managers. The proposed hypothesis is as follows:

H3: Enterprises with a higher percentage of ownership by managers will have a lower level of disclosure of sustainable development information.

\subsubsection{Foreign Ownership and Disclosure of Sustainable Development Information}

In the context of Vietnam, an empirical study of 122 listed companies on Ho Chi Minh stock market in the period 20152018 showed that foreign ownership has no effect on the level of voluntary disclosure (Nguyen, Nguyen \& Nguyen, 2020). Chambers, Chapple, Moon and Sullivan (2003) studied the sustainability report of the top 50 companies in seven Asian countries and showed that very few Asian companies publish as much information on sustainability as foreign-invested companies from the UK and Japan. The average value of the seven countries was $41 \%$, much lower than that of British companies (98\%) and Japanese companies (96\%).

Previous research by La Porta, Lopez-de-Silanes, Shleifer and Vishny (2000) confirms that foreign shareholders face higher risks than domestic shareholders. These authors state that the potential risks related to business that foreign shareholders incur such as political risks and legal protection are not tight. Especially in emerging markets like Vietnam, the problem of information asymmetry is even higher. Therefore, foreign-owned companies have a greater need for disclosure of sustainable development information, which serves as a means to track owners' activity against managers. So, the proposed hypothesis is as follows:

H4: Enterprises with higher foreign ownership will have higher level of disclosure of sustainable development information.

\subsubsection{State Ownership and Disclosure of Sustainable Development Information}

Vu (2012); Yang, Wang, and Zhang (2013) found a negative relationship between state ownership and the level of voluntary non-financial disclosure. These studies have argued that state ownership is the ownership by all the citizens, so there is no real owner, thus, the lack of real ownership rights prevents direct control from the owner resulting in corruption and weak corporate governance. Thus, the manager will act for personal interest rather than for the benefit of shareholders. Therefore, the level of voluntary disclosure of sustainable development information is low. Besides, state-owned companies often have little incentive to maximize profits because the company's profits and reinvestment capital are guaranteed by the state. Therefore, the company has no motivation to voluntarily disclose information to outside to increase the company's value and attract investment capital. So, the proposed hypothesis is as follows:

H5: The higher the percentage of state ownership, the lower the level of disclosure of sustainable development information.

\subsubsection{Profitability and Disclosure of Sustainable Development Information}

According to Nguyen, Pham and Nguyen (2020), profitability reveals the ability to make a profit from all three types of business activities of a firm - operating, investing and financing activities. It shows the efficiency of using all available resources of a firm to make a profit. In previous studies on the disclosure of sustainable development information of listed companies, the profitability factor was always mentioned as one of the important factors such as research by (Andrikopoulos \& Kriklani, 2012; Haniffa, Cooke \& Culture, 2005). According to Chambers, Chapple, Moon and Sullivan (2003) companies with high sustainability indexes are often expected to have high profits. Besides, Said, Zainuddin, and Haron (2009) argues that there is a close and positive link between profit and sustainability information disclosure. They believe that high-profit companies will actively disclose socio-economic-environmental information to demonstrate their role in community welfare activities, and confirm the existence of a surname. Ehsan and Kaleem (2012) also concluded the positive impact of profitability on the disclosure of sustainability information of businesses. Therefore, the following hypothesis for the impact of profitability on the disclosure of sustainable development information is proposed: 
H6: Higher profitability enterprises will have a higher level of disclosure of sustainable development information

\subsubsection{Financial Leverage and Disclosure of Sustainable Development Information}

In countries where financial institutions are a major source of corporate capital, companies with high financial leverage tend to disclose more information to creditors, suppliers and investors, aiming to create more confidence with creditors that the company can meet its financial obligations and improve the chance of getting good investment from financial institutions. Previous research by Yang, Wang and Zhang (2013) has found a significant correlation between financial leverage and the level of disclosure of companies. Empirical research by Barako (2007) found that the financial leverage of Portuguese companies has a positive relationship with the disclosure of sustainability information of these companies. However, research by Andrikopoulos and Kriklani (2012) has found that companies with high levels of financial leverage tend to reduce the level of information disclosure because preparation of disclosure of sustainable development information is a procedure costly. Therefore, the hypothesis about the impact of financial leverage on the disclosure of sustainable development information is stated as follows:

H7: Enterprises with higher financial leverage will have a higher level of disclosure of sustainable development information.

\section{Data and Research Methodology}

\subsection{Data Collection}

In this research, the data are obtained from the most comprehensive financial database in Vietnam, which is Vietstock Database. The research sample data includes 120 manufacturing companies listed on the Vietnam stock market in 2019. To avoid the problem of outliners, before analyzing by statistical techniques, the data is winsorized at the $5 \%$ level.

\subsection{Model}

Based on the above hypotheses, the paper proposes a model to test the hypothesis of the impact of factors on the disclosure of sustainable development information (SDI) as follows:

$$
\begin{aligned}
\mathrm{SDI}= & \beta_{0}+\beta_{1} \mathrm{SIZE}+\beta_{2} \mathrm{BOD}+\beta_{3} \mathrm{MGO}+\beta_{4} \mathrm{FRO}+ \\
& \beta_{5} \mathrm{STO}+\beta_{6} \mathrm{ROE}+\beta_{7} \mathrm{LEV}+\varepsilon_{\mathrm{i}}
\end{aligned}
$$

where

SDI: Sustainability Disclosure Index; SIZE: Firm Size
BOD: Board of Directors Independent

MGO: Managers Ownership

FRO: Foreign Ownership; STO: State Ownership

ROE: Return on Equity; LEV: Financial leverage

$\beta$ : Estimate parameters; $\varepsilon$ : Error terms.

\subsection{Variables Measurement}

\subsubsection{Dependent Variable}

To assess the level of disclosure of sustainable development informationa in the annual report, this study is based on the research conducted by Muttanachai (2015) and the handbook published by the State Securities Commission of Vietnam and the International Finance Corporation (IFC) about the guidelines for preparing a sustainable development report for Vietnamese enterprises. This research has established a list of 88 criteria to determine the information disclosure index on sustainable development. The indicators are coded by scoring 1 if the indicator is disclosed by the company and zero if the indicator is not disclosed. The scores of all these indicators are then added together to get the total score for each company. The model of disclosure of sustainable development information measures the total number of points disclosed by a company as follows: SDI = $\sum^{\mathrm{nj}}{ }_{\mathrm{i}=1} \mathrm{di} / \mathrm{nj}$, where di is 1 if the indicator is disclosed and 0 if the indicator is not disclosed, $\mathrm{nj}$ is the maximum number of indicators for companies $\mathrm{j}$ and $\mathrm{nj} \leq 88$.

\subsubsection{Independent Variables}

Table 1 presents independent variables and measurements.

\section{Results and Discussion}

\subsection{Descriptive Statistics and Correlation Matrix of Variables}

Table 2 presents descriptive statistics of the variables.

Table 3 shows the correlation between independent variables with low correlation coefficients between variables, so the multicollinearity phenomenon between independent variables has not been found in the regression model. Next, the paper also conducted classical assumption tests to determine the accuracy of the regression model.

\subsection{Test of Regression Assumptions}

In this research, there are four classical regression model assumption tests that will be implemented, namely, the normality test, multicollinearity test, heteroscedasticity test, and autocorrelation test. The normality test is used to assess whether the regression model meets the requirement of a 
Table 1: Independent variables measurement

\begin{tabular}{|c|c|c|c|}
\hline Variables & Measurements & Expected relationship & Previous studies \\
\hline SIZE & Natural logarithm of company's average total assets & Positive & $\begin{array}{l}\text { Jizi, Salama, Dixon and } \\
\text { Stratling (2014) }\end{array}$ \\
\hline BOD & $\begin{array}{l}\text { Percentage of independent members of the Board of } \\
\text { Directors }\end{array}$ & Positive & $\begin{array}{l}\text { Arifur, Mohammad and } \\
\text { Javed (2013) }\end{array}$ \\
\hline MGO & $\begin{array}{l}\text { Percentage of shares owned by the managers over } \\
\text { the total number of shares issued by the company }\end{array}$ & Negative & $\begin{array}{l}\text { Roshima, Yuserrie and } \\
\text { Hasnah (2009) }\end{array}$ \\
\hline FRO & $\begin{array}{l}\text { Percentage of shares owned by foreign shareholders } \\
\text { over the total number of shares issued by the } \\
\text { company }\end{array}$ & Positive & $\begin{array}{l}\text { Roshima, Yuserrie and } \\
\text { Hasnah (2009) }\end{array}$ \\
\hline STO & $\begin{array}{l}\text { The percentage of shares owned by the state over } \\
\text { the total number of shares issued by the company }\end{array}$ & Negative & Ehsan and Kaleem (2012) \\
\hline ROE & $\begin{array}{l}\text { Net income after tax over average total stockholders } \\
\text { equity }\end{array}$ & Positive & $\begin{array}{l}\text { Sadia, Tariq and Saba } \\
\text { (2015) }\end{array}$ \\
\hline LEV & Total debt to total equity & Positive & $\begin{array}{l}\text { Sadia, Tariq and Saba } \\
(2015)\end{array}$ \\
\hline
\end{tabular}

Table 2: Descriptive statistics of the variables

\begin{tabular}{|c|c|c|c|c|}
\hline Variables & Mean & Standard Deviation & Maximum & Minimum \\
\hline SDI & 0.398 & 0.139 & 0.743 & 0.141 \\
\hline SIZE & 3.580 & 3.938 & 4.795 & 1.610 \\
\hline BOD & 0.692 & 0.156 & 1.000 & 0.285 \\
\hline MGO & 0.123 & 0.188 & 0.886 & 0.000 \\
\hline FRO & 0.182 & 0.162 & 0.512 & 0.000 \\
\hline STO & 0.163 & 0.232 & 0.981 & 0.000 \\
\hline ROE & 0.332 & 0.212 & 0.950 & -0.13 \\
\hline LEV & 0.459 & 0.168 & 0.812 & 0.036 \\
\hline
\end{tabular}

Table 3: Correlations matrix

\begin{tabular}{|c|c|c|c|c|c|c|c|c|}
\hline Variables & SDI & SIZE & BOD & MGO & FRO & STO & ROE & LEV \\
\hline SDI & 1.000 & & & & & & & \\
\hline SIZE & 0.556 & 1.000 & & & & & & \\
\hline BOD & 0.128 & 0.123 & 1.000 & & & & \\
\hline MGO & -0.116 & -0.955 & -0.018 & 1.000 & & & & \\
\hline FRO & 0.198 & 0.399 & -0.024 & -0.112 & 1.000 & & & \\
\hline STO & -0.028 & 0.123 & -0.056 & -0.326 & -0.043 & 1.000 & & \\
\hline ROE & 0.286 & 0.116 & 0.086 & 0.235 & -0.193 & 0.286 & 1.000 & \\
\hline LEV & 0.215 & 0.216 & 0.235 & -0.203 & 0.238 & -0.234 & -0.025 & 1.000 \\
\hline
\end{tabular}

normal distribution or not. In other words, this test is used to evaluate whether the dependent variable and independent variables are normally distributed. The normality test in this study will be using the Kolmogorov-Smirnov test. Besides the correlations matrix, multicollinearity test aims to test whether the regression model found a correlation among the independent variables. Multicollinearity in this paper will be performed using the Tolerance Value and Variance 
Inflation Factor (VIF). Next, this research uses Scatterplot to test the heteroscedasticity of the regression model. The heteroscedasticity test examines whether the regression model has an unequivalent variance from one residual observation to the other observation. Finally, in this research, the Durbin-Watson test is used to determine whether there is autocorrelation of the regression model.

Table 4 shows the coefficients of the model and the autocorrelation statistics, the Durbin-Watson coefficient is 1.982 which is approximately equal to 2 , so the regression model has no autocorrelation phenomenon. After all the four classical assumption tests of the regression model described above produce good results, the hypothesis testing will be performed. Following other researchers, multiple regression analyses will be performed to test the effect of the explanatory variables on the dependent variable in a linear equation.

\subsection{Regression Results}

Table 5 shows that five variables have a statistically significant positive effect on disclosure of sustainable development information of manufacturing companies listed on Vietnam stock market includes firm size (SIZE), independent of board of directors (BOD), foreign ownership (FRO), profitability (ROE), and financial leverage (LEV). State ownership (STO) has a statistically significant negative effect on disclosure of sustainable development information of manufacturing companies listed on Vietnam stock market.

\subsection{Discussion}

The results show that firm size has a statistically positive effect on the disclosure of sustainable development information. Therefore, hypothesis 1 (H1) is accepted, that is, the bigger the business the higher the disclosure of sustainable development information. This is consistent with the results of many previous kinds of research such as (Cowen, Ferreri \& Parker, 1987; Haniffa \& Cooke, 2005; Nazli, 2007; Said, Zainuddin \& Haron, 2009). Large companies often have great economic potential, so they have the ability to disclose more information about sustainable development. In addition, as a general rule, it can be seen that, when a company has a larger asset size, it will have more transactions generated and more contact with many different stakeholders. Therefore, in order to build and enhance the confidence of stakeholders, assure them of the company's sustainable development; apart from paying attention to economic development activities, they are also interested in the implementation of social responsibility. Therefore, the disclosure of information on sustainable development is always focused on these companies.

The results show that the independence of the board of directors has a statistically positive effect on the disclosure of sustainable development information. Therefore, hypothesis 2 (H2) is accepted, that is, the higher the level of independent members of the board of directors of the business, the higher the disclosure of sustainable development information. This is consistent with the results of some previous researches such as (Gray, Kouhy \& Lever, 1995; Le, 2005; Mohamed, 2012). This shows that the independent members of the board of directors of manufacturing companies listed on the Vietnam stock market are able to support the disclosure of social responsibility activities for sustainable development to reduce information asymmetry between insiders and outsiders of the company.

The results show that there is no relationship between the ownership of managers and the disclosure of sustainable development information of enterprises. It implies that

Table 4: Testing for autocorrelation

\begin{tabular}{|c|c|c|c|c|c|}
\hline \multicolumn{7}{|c|}{ Model Summaryb } \\
\hline Model & $\mathbf{R}$ & R square & Adjusted R square & Std. error of the estimate & Durbin-Watson \\
\hline 1 & $.635^{\mathrm{a}}$ & .392 & .371 & .103126 & 1,982 \\
\hline a. Predictors: (Constant), SIZE, BOD, MGO, FRO, STO, ROE, LEV \\
\hline
\end{tabular}

Table 5: Regression results

\begin{tabular}{|l|c|c|c|c|c|c|c|}
\hline \multicolumn{1}{|c|}{ Variables } & SIZE & BOD & MGO & FRO & STO & ROE & LEV \\
\hline SDI & $0.3965^{\star \star *}$ & $0.2993^{* \star *}$ & -0.1157 & $0.2731^{\star \star *}$ & $-0.2646^{\star * *}$ & $0.1939^{* *}$ & $0.1664^{*}$ \\
\hline t-value & 4.7411 & 2.8626 & -1.7850 & 2.6962 & -2.5628 & 2.4893 & 2.1485 \\
\hline Constant & \multicolumn{7}{|c|}{$0.068(0.048)$} \\
\hline Adjusted R-squared & \multicolumn{7}{|c|}{37.12} \\
\hline
\end{tabular}

${ }^{*},{ }^{* *}$, and ${ }^{* * *}$ indicate significance at the $10 \%, 5 \%$ and $1 \%$ level, respectively. 
hypothesis $3(\mathrm{H} 3)$ is not accepted. This result is similar to the research by Roshima, Yuserrie and Hasnah (2009). Many previous studies on this issue give conflicting results including positive effects, negative effects or no effects showed; the correlation relationship between managers' ownership and sustainability disclosure is not really clear. In the context of Vietnam, this result reflects the fact that managers who hold some ownership percentage still do not affect the level of sustainability information disclosure. This shows that the benefits for the owners from the disclosure of sustainable development information of these businesses are not great.

The results indicate that foreign ownership has a statistically positive effect on the disclosure of sustainable development information. Therefore, hypothesis $4(\mathrm{H} 4)$ is accepted. This result adds to the evidence by Chambers, Chapple, Moon and Sullivan (2003) who stated that, among sample research enterprises, foreign-invested enterprises had a higher level of disclosure of sustainable development information than businesses with domestic investment. It can be seen that the participation of foreign investors in the ownership of businesses in the manufacturing sector listed on Vietnam stock market has contributed to the increase in the disclosure of sustainable development information of these businesses. This is relatively appropriate when the statistical results show that the status of the disclosure of sustainable development information of enterprises in Vietnam is not high. Meanwhile, foreign investors from developed markets display a high level of information transparency, so that their involvement in the business has an impact on the requirement to provide more information. Their clarity and transparency will have a positive impact on the disclosure of sustainable development information of Vietnamese businesses.

Regarding state ownership, the results show a statistically significant negative effect on disclosure of sustainable development information of manufacturing companies listed on Vietnam stock market. Therefore, hypothesis 5 (H5) is accepted. This result is consistent with the research by $\mathrm{Vu}$ (2012); Yang, Wang and Zhang (2013). This result may be explained by the fact that state ownership is the ownership by the entire population, so there is no real owner; the lack of real ownership rights prevents direct control from the owner resulting in corruption and weak corporate governance, so that managers will act for their personal interest rather than the interests of shareholders. Therefore, the level of information disclosure on sustainable development is low.

The results show that profitability measured by return on equity (ROE) has a statistically positive effect on the disclosure of sustainable development information. Therefore, hypothesis 6 (H6) is accepted. This result shows that the more profitable the business, the higher the level of sustainable development information disclosure. This result is also consistent with the results of many researchers such as (Giner, 1997; Li, Griffin, Yue \& Zhao, 2013; Sadia, Tariq \& Saba, 2015; Walace \& Naser, 1995). This shows that businesses with high profits are easier to produce and disclosure of sustainable development information. As a result, it also helps businesses attract the attention of investors and it also shows that beyond focus on the profit targets, they also emphasize sustainable development.

As regards financial leverage, the results show a statistically significant positive effect on the disclosure of sustainable development information of manufacturing companies listed on the Vietnam stock market. Therefore, hypothesis 7 (H7) is accepted. This shows that companies with high financial leverage tend to disclose more information about sustainable development to provide creditors, suppliers, and investors with greater assurance for creditors that the company can meet its financial obligations and increasing the chances of getting good investments from financial institutions. This result is consistent with some previous studies including Yang, Wang and Zhang (2013).

\section{Conclusion}

By empirical examining the sustainability disclosure in the annual report and the sustainability report of the business, the research results show that there is a large difference in the disclosure of sustainable development information between listed companies in Vietnam, compared to companies in other emerging economies in the region and developed market over the world. The research results also confirmed the stakeholder's theory, agency theory, proprietary cost theory, signaling theory are appropriate. This research reveals that five factors have a statistically significant positive effect on disclosure of sustainable development information of manufacturing companies listed on Vietnam stock market: firm size (SIZE), independence of the board of directors (BOD), foreign ownership (FRO), return on equity (ROE), and financial leverage (LEV). The results also indicate that state ownership (STO) has a statistically significant negative effect on disclosure of sustainable development information of manufacturing companies listed on Vietnam stock market.

\section{References}

Ahmad, N.S.M. (2014). The attitudes of accountants towards environmental disclosure (CED) in Libya: a review and future direction. World Journal of Entrepreneurship, Management and Sustainable Development, 10(1), 119-127.

Andrikopoulos, A., \& Kriklani, N. (2012). Environmental disclosure and financial characteristics of the firm: the case of Denmark. Corporate Social Responsibility and Environmential Management, 20(1), 55-64. 
Arifur, R.K., Mohammad, B.M., \& Javed, S. (2013). Corporate governance and corporate social responsibility disclosures: evidence from an emerging economy. Journal of Business Ethics, 114(2), 207-223.

Baimukhamedova, A., Baimukhamedova, G., \& Luchaninova, A. (2017). Financial disclosure and the cost of equity capital: the empirical test of the largest listed companies of Kazakhstan. Journal of Asian Finance, Economics and Business, 4(3), 5-17. https://doi.org/10.13106/jafeb.2017.vol4.no3.5

Chambers, E., Chapple, W., Moon, J., \& Sullivan M. (2003). CSR in Asia: A seven country study of CSR website reporting. No. 09-2003 ICCSR Research Paper Series, UK. Retrieved January 15, 2020 from http://citeseerx.ist.psu.edu/viewdoc/ download?doi=10.1.1.470.5464\&rep=rep1\&type $=$ pdf

Cowen, S.S., Ferreri, L.B., \& Parker, L.D. (1987). The impact of corporate characteristics on social responsibility disclosure: A typology and frequency-based analysis. Accounting, Organizations and Society. 12(2), 111-122.

Ehsan, S., \& Kaleem, A. (2012). An Empirical investigation of the relationship between corporate social responsibility and financial performance: evidence from manufacturing sector of Pakistan. Journal of Basic and Applied Scientific Research, 2(3), 2909-2922.

Fadun, O.S. (2014). Corporate social responsibility (CSR) practices and stakeholders expectations: the Nigerian perspectives. Research in Business Management, 1(2), 2330-8362.

Giner, B.I. (1997). The influence of company characteristics and accounting regulation on information disclosed by Spanish firms. European Accounting Review, 6(1), 45-68.

Gray, R., Kouhy, R., \& Lever, S. (1995). Methodological themes: constructing a research database of social and environmental reporting by UK companies. Accounting Auditing \& Accountability Journal, 8(2), 78-101.

Habbash, M. (2016). Corporate governance and corporate social responsibility disclosure: evidence from Saudi Arabia. Social Responsibility Journal, 12(4), 740-754.

Haniffa, R.M., \& Cooke, T.E. (2005). Culture, corporate governance and disclosure in Malaysian corporations. Abacus, $38(3), 317-349$.

Harry, D., \& Linda, D. (1994). Accounting choice in troubled companies. Journal of Accounting and Economics, 17(1-2), 113-143.

Ho, L.J., \& Taylor, M. E. (2007). An empirical analysis of triple bottom-line reporting and its determinates: evidence from the United States and Japan. Journal of International Financial and Accounting, 18(2), 123-150.

Ho, N.T.T., \& Liafisu, S.Y. (2014). Investigating the link between CSR and financial performance - evidence from Vietnamese listed companies. British Journal of Arts and Social Sciences, 17(1), 2046-9578.

Hussainey, K., Elsayed, M., \& Razik, M.A. (2011). Factors affecting corporate social responsibility disclosure in Egypt. Corporate Ownership and Control, 8(4-4), 432-443.
Huynh, Q.L. (2020). A triple of corporate governance, social responsibility and earnings management. Journal of Asian Finance, Economics and Business, 7(3), 29-40. https://doi. org/10.13106/jafeb.2020.vol7.no3.29

Jizi, M., Salama, A., \& Dixon, R. (2014). Stratling. Corporate governance and corporate social responsibility disclosure: evidence from the US banking sector. Journal of Business Ethics, 125(4), 601-615.

John, K., \& Senbet, L.W. (1998). Corporate governance and board effectiveness. Journal of Banking \& Finance, 22(4), 371-403.

La Porta, R., Lopez-de-Silanes, L.A., Shleifer, \& Vishny, R. (2000). Investor protection and corporate governance. Journal of Financial Economics, 58(1-2), 3-27.

Le, T.N. (2015). Determinants of corporate social responsibility disclosure: the case of Vietnam. Proceedings of the International Conference on Accounting (pp. 252-262), May 22-23, Danang, Vietnam.

Lee, W.J. (2018). Group-affiliated firms and corporate social responsibility activities. Journal of Asian Finance, Economics and Business, 5(4), 127-133. https://doi.org/10.13106/ jafeb.2018.vol5.no4.127

Li, K., Griffin, D., Yue, H., \& Zhao, L. (2013). How does culture influence corporate risk-taking? Journal of Corporate Finance, $23,1-22$.

Mohamed, A.O. (2012). Theoretical perspectives on corporate social responsibility disclosure: a critical review. International Journal of Accounting and Financial Reporting, 5(2), 2162-3082.

Muttanachai, S. (2017). Sustainable development reporting: evidence from Thailand. Asian Social Science, 11(13), 19112017.

Nazli, A.M.G. (2007). Ownership structure and corporate social responsibility disclosure: some Malaysian evidence. Corporate Governance International Journal of Business in Society, 7(3), 251-266.

Nguyen, A.H., Pham, H.T., \& Nguyen, H.T. (2020). Impact of working capital management on firm's profitability: empirical evidence from Vietnam. Journal of Asian Finance, Economics and Business, 7(3), 115-125. https://doi.org/10.13106/ jafeb.2020.vol7.no3.115

Nguyen, T.M.H., Nguyen, N.T., \& Nguyen, H.T. (2020). Factors affecting voluntary information disclosure on annual reports: listed companies in Ho Chi Minh City stock exchange. Journal of Asian Finance, Economics and Business, 7(3), 53-62. https:// doi.org/10.13106/jafeb.2020.vol7.no3.53

Roshima, S., Yuserrie, H.Z., \& Hasnah, H. (2009). The relationship between corporate social responsibility disclosure and corporate governance characteristics in Malaysian public listed companies. Social Responsibility Journal, 5(2), 212-226.

Sadia, M., Tariq, A., \& Saba, S. (2015). The effect of corporate governance elements on corporate social responsibility (CSR) disclosure: an empirical evidence from listed companies at KSE Pakistan. International Journal of Financial Studies, 3, 530-556. 
Said, R., Zainuddin, Y.H., \& Haron, H. (2009). The relationship between corporate social responsibility disclosure and corporate governance characteristics in Malaysian public listed companies. Social Responsibility Journal, 5(2), 212-226.

Tagesson, T., Blank, V., Broberg, P., \& Collin, S.O. (2009). What explains the extent and content of social and environmental reporting in Swedish listed corporations? Corporate Social Responsibility and Environmental Management, 16(6), 352-364.

$\mathrm{Vu}$, K.B.A.H. (2012). Determinants of voluntary disclosure for Vietnamese listed firms. Canberra, Australia: Doctorial dissertation, Curtin University, Perth, Western Australia.
Walace, R.S., \& Naser, K. (1995). Firm- specific determinants of the comprehensiveness of mandatory disclosure in the corporate annual reports of firms listed on the stock exchange of Hong Kong. Journal of Accounting and Public Policy, 14(4), 311-368.

Yang, L., Wang, L., \& Zhang, X. (2013). Determinants and features of voluntary disclosure in the Chinese stock market. China Journal of Accounting Research, 6(4), 265-285. 
